\title{
磁性皮膜で被覆した圧粉磁心の磁気特性評価
}

\author{
黄 晸煥，服部 毅，金子 裕治
}

(株) 豊田中央研究所，４ 480-1192 長久手市横道 41-1。

\section{Magnetic Properties of Iron Core made from Powders Coated with Magnetic Insulative Films}

\author{
Junghwan HWANG, Takeshi HATTORI and Yuji KANEKO \\ Toyota Central R\&D., Inc., 41-1 Yokomichi, Nagakute 480-1192, Japan.
}

Received August 29, 2014

\begin{abstract}
In order to improve the permeability $\mu$ and magnetic flux density $B$ s of powder magnetic core, we characterized the iron powder compact coated with spinel ferrite particles. Their $\mu$ and $B$ s are higher than those of iron powder compact coated with nonmagnetic insulative films, having the same resistivity; $B_{2 \mathrm{k}}$ of $1.4 \mathrm{~T}$, density of $7.79 \mathrm{Mg} / \mathrm{m}^{3}$, and resistivity of $70 \mu \Omega \cdot \mathrm{m}$ are achieved.
\end{abstract}

KEY WORDS

magnetic insulative film, spinel ferrite, powder magnetic core, permeability, magnetic flux density

\section{1 緒 言}

圧粉磁心は, 表面を絶縁皮膜でコーティングした磁性粉末 を成形して作製されているので, (1)等方的な磁気特性による 3次元的な磁気回路設計が可能であること, (2) 比抵抗が高い ため, 高周波域で渦電流損失が低いことなどの特長を有する. その特長を活用し，電子機器用のチョークコイル ${ }^{1-3)}$ やイン ジェクタの噴射弁 ${ }^{4}$, モータ5,6などへの応用が盛んである. 然 しながら, 現状の圧粉磁心は, その磁束密度や強度が電磁鋼 板に比べて低い問題がある. 通常の圧粉磁心は粒径 $100 \mu \mathrm{m}$ 前 後の磁性粉末の集合体であり, 粉末表面の絶縁皮膜にはSi樹 脂やリン酸塩皮膜など, 非磁性皮膜が被覆されているので, 粉末内には反磁界の影響による磁気的抵抗が生じ, 磁界に対 して磁化されにくく, 高磁束密度が得られにくい, それに対 して, 磁性を有する絶縁皮膜は粉末間の磁気抵抗が緩和され, 磁化されやすく, 透磁率向上が期待できる. 高い比抵抗值を 有するスピネル型フェライトを絶縁皮膜へ導入する研究につ いては, $100 \mathrm{kHz}$ 以上の高周波域での圧粉磁心の透磁率を向上 させた研究例があり, 例えば, 阿部ら ${ }^{7,8)}$ はスピネル型フェラ イト $\mathrm{MFe}_{2} \mathrm{O}_{4}(\mathrm{M}=\mathrm{Ni}, \mathrm{Zn}, \mathrm{Fe}, \mathrm{Mn}$ など) の高透磁率, 高電気抵 抗の特性を利用し, $10 \mu \mathrm{m}$ 以下の金属微粒子表面に数十 $\mu \mathrm{m}$ 以 上のスピネル型フェライト皮膜をフェライトメッキ法 ${ }^{9,10)}$ で 被覆して, $100 \mathrm{kHz}$ 以上の高周波対応の軟磁性材料を開発して
いる. また廣田ら ${ }^{11,12)}$ は，大きなせん断応力を付与可能なメ カノフュージョンを用いて粉末表面にフェライト粉を被覆し た粉末を作製した後, 成形, パルス通電焼結を施し, 密度 $6 \mathrm{Mg} / \mathrm{m}^{3}$ 程度のコンポジットを作製した。

然しながら,これらの研究は $100 \mathrm{kHz}$ 以上の高い周波数領 域での使用が前提となるため, 微粉表面には厚い皮膜をつけ ており，その為に飽和磁化 Bs が $1.5 \mathrm{~T}$ 以下の值しか得られて いない. それに対して, 本研究のねらいは, 使用周波数が数 百 $\mathrm{Hz}$ の低い領域における絶縁皮膜の磁性化と高密度成形の 組合せによる圧粉磁心の高透磁率化と高磁束密度化の両立で ある. 本研究では, 透磁率 (ここでは, 磁束密度 $B_{2 \mathrm{k}}(H=2000$ $\mathrm{A} / \mathrm{m}$ での磁化 $\left.)^{13}\right)$ に に及ぼす絶縁皮膜の磁性の有無, 磁性皮膜 の飽和磁化打よび鉄粉粒径などの影響を計算で求めた. その 後, 純鉄球状粉とスピネル型フェライト粉を混合して, 表面 にフェライト皮膜を生成させた純鉄粉を成形して圧粉体を作 り, 特性評価を行った. その計算值と実験値を比較評価して 磁性皮膜の効果について検証し, 磁性絶縁皮膜による圧粉磁 心の絶縁化と高飽和磁化への可能性について検討した。

\section{2 実験方法}

2.1 磁束密度の計算

磁束密度の計算は, 河瀬ら ${ }^{14)}$ が提案したモデルを用いて, 
磁界の強さにおける磁束密度を計算した. その圧粉成形体の モデルと磁束密度 $B$ の計算式を Fig. 1 に示す. 粉末粒径 $\left(1_{2}\right)$ と ギャップとなる絶縁皮膜の膜厚 $(\mathrm{g})$ で構成される粒子 1 個に生 じる磁束密度を計算する. 計算式に使ったパラメータの数值 は次のように求めた. 鉄粉の磁気抵抗率 $(\mathrm{v})$ には, 被覆処理し ていない原料粉の鉄粉を $1568 \mathrm{MPa}$ 成形圧力で成形したリン グ試験片で求めた磁束密度 $B_{2 k}$ の值である $1.45 \mathrm{~T}$ をいた. 絶 縁皮膜の磁気抵抗率 $\left(\mathrm{v}_{0}\right)$ は絶縁皮膜の種類により異なる值を 用いた. まず非磁性皮膜の場合は, 真空中の磁気抵抗率を用 いた. 次に磁性皮膜の場合は, スピネル型フェライトの磁化 が $2000 \mathrm{~A} / \mathrm{m}$ で飽和すると見なすことを前提に, スピネル型 フェライトの飽和磁化の值をそのまま磁気抵抗率 $\left(\mathrm{v}_{0}\right)$ として 用いた。

\section{2 試験片作製扔よび特性評価の条件}

Fig. 2 に試験片の作製手順を示す. 原料磁性粉末は, 粒度分

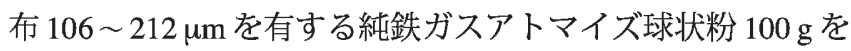
用いた．その原料磁性粉末の表面に被覆するスピネル型フェ ライト粉は, 粒径は $1 \mu \mathrm{m}$ 以下の高純度化学製の $\mathrm{Mn}_{0.5} \mathrm{Zn}_{0.5} \mathrm{Fe}_{2} \mathrm{O}_{4}$ を用いた. そのフェライト粉の飽和磁化を測定した結果, $0.2 \mathrm{~T}$ であった. スピネル型フェライト粉を原料磁性粉末に対して 0.1 1.0 mass\%になるよう秤量し, 原料磁性粉末と一緒に 500 $\mathrm{ml}$ のポリ瓶に投入後, ポリ瓶を速度 $300 \mathrm{rpm}$ の回転ミルを用 いて被覆処理を行った。均一に被覆させるため, 混合時間は $100 \mathrm{~h}$ とした. 一方, 比較材である非磁性絶縁皮膜としてリン 酸塩皮膜の被覆粉を用いた. $100 \mathrm{ml}$ ビーカーに同じ原料磁性 粉末 $100 \mathrm{~g}$ を入れた後, リン酸塩溶液 ${ }^{15)}\left(\mathrm{SrO}, \mathrm{H}_{3} \mathrm{BO}_{3}, \mathrm{H}_{3} \mathrm{PO}_{4}\right.$ を

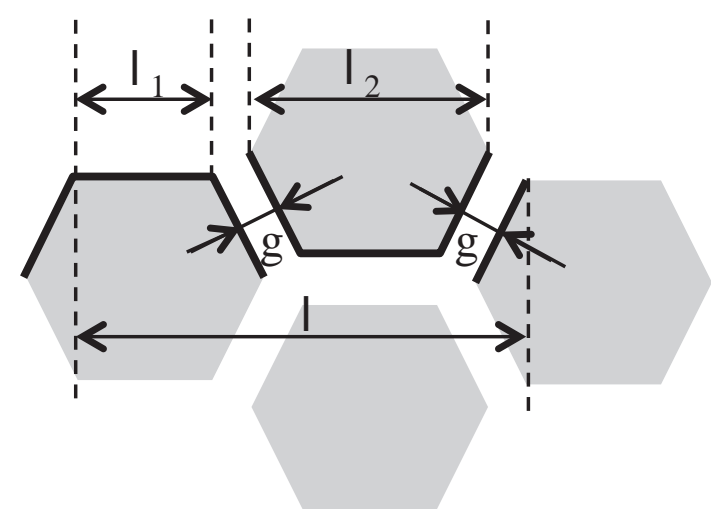

$$
\int H \mathrm{dl}=\mathrm{v} B\left(\mathrm{l}_{1}+\mathrm{I}_{2}\right)+2 \mathrm{v}_{0} B \frac{2}{\sqrt{3}} \mathrm{~g}=H \mathrm{l}
$$

$H$ : magnetic field intensity

$B$ : magnetic flux density

$v$ : magnetic reluctivity in magnetic substance

$\mathrm{v}_{0}$ : magnetic reluctivity in vacuum

$\mathrm{I}$ : unit length of powder magnetic core

$\mathrm{I}_{2}$ : powder diameter $\left(\mathrm{I}_{1}=\mathrm{I}_{2} / 2\right)$

$\mathrm{g}:$ thickness of insulative film

Fig. 1 The analyzed model and calculation formula of magnetic flux density $B$ for powder magnetic core.

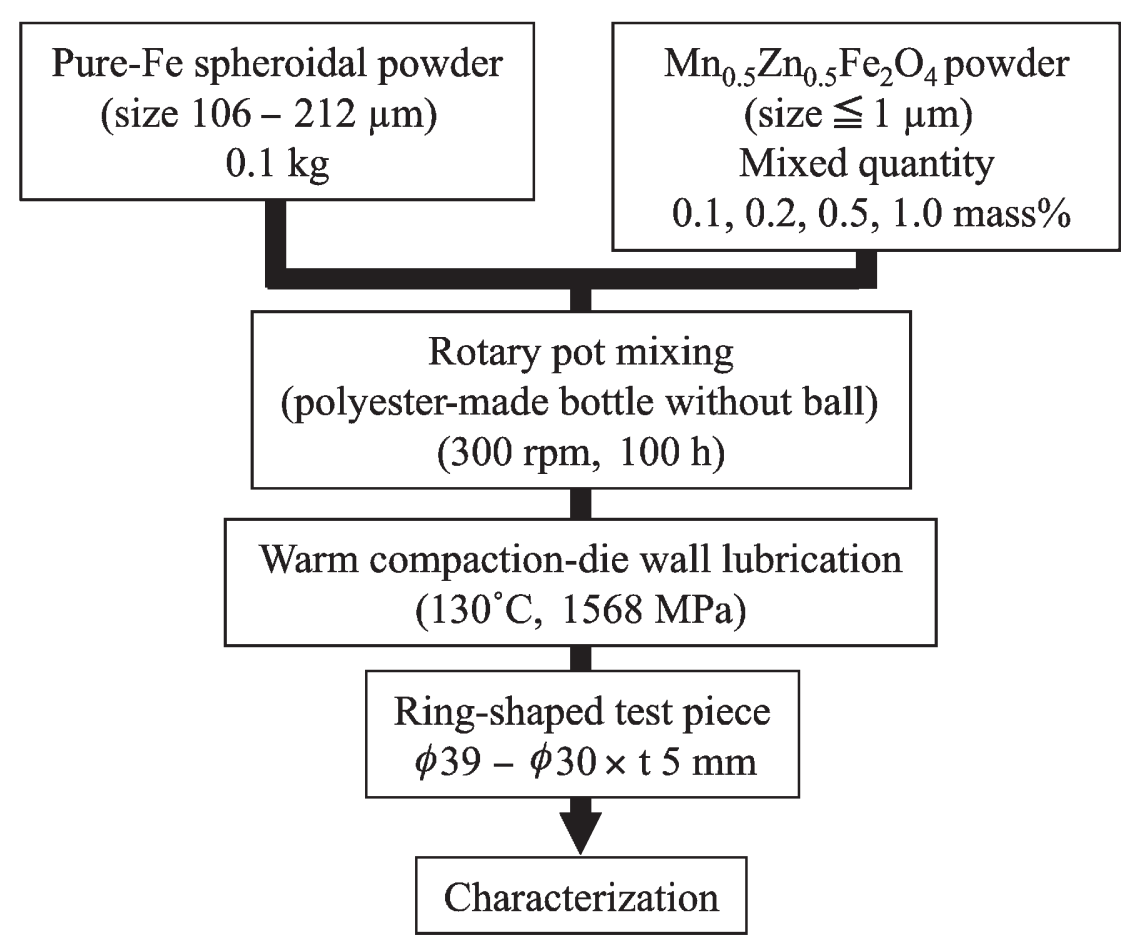

Fig. 2 Experimental procedure of powder magnetic core using magnetic insulting film. 
$1.5: 1.0: 4.0$ のモル比となるよう調製)を投入し，スパーテル で軽く擋汼後, $523 \mathrm{~K}$ の乾燥炉に入れて, 大気中で $30 \mathrm{~min}$ 乾 燥後, 解粉して作製した.

試験片形状は $\phi 39-\phi 30 \times \mathrm{t} 5 \mathrm{~mm}$ のリング状とした。その 成形には, ステアリン酸リチウムを用いた金型潤滑温間成形 16,17)を用いた. 金型温度を $423 \mathrm{~K}$ に加熱保持した後, $1568 \mathrm{MPa}$ の圧力で成形した。 なお，成形時に内部潤滑剤および樹脂は 添加していない. その後, 成形体密度, 比抵抗および磁気特 性の評価を行った. 成形体密度は, 成形体の重量と形状から 測定した寸法密度で，比抵抗は，アドバンテスト製のマイク ロオームメータ(型番: R6561)を用いた4端子法で測定した。 静磁場特性の測定にはリング試験片に, $\phi 0.5 \mathrm{~mm}$ の被覆銅線 を検出 80 ターン, 励磁 240 ターン巻いて測定試料とした. 測 定装置は東英工業製の直流自記磁束計 TRF-5を使用した。な お，本文中で $B_{\mathrm{Xk}}$ は， $\mathrm{X} \mathrm{kA} / \mathrm{m}$ で測定された磁束密度を示す。 被覆粉の表面および圧粉体の断面を走査型電子顕微鏡(SEM) で観察した。

\section{3 結 果}

3.1 計算で求めた絶縁皮膜の膜厚における磁束密度 $B_{2 \mathrm{k}}$ の傾向 絶縁皮膜の非磁性化と磁性化による影響を調べるため, 非 磁性皮膜と飽和磁化0.1 Tを有する磁性皮膜における絶縁皮膜 の膜厚と磁束密度 $B_{2 \mathrm{k}}$ の関係の計算結果をFig. 3に示す. 粉末 粒径は $100 \mu \mathrm{m}$ とした。 その結果，同じ膜厚において，飽和磁 化が $0.1 \mathrm{~T}$ 程度の磁性皮膜でも非磁性皮膜に比べて磁束密度 $B_{2 \mathrm{k}}$ が増加することがわかった. 非磁性皮膜の代わりに磁性を 持つ皮膜を導入することで, 圧粉磁心の磁束密度の向上の可 能性があることが分かった。

Fig.4に絶縁皮膜の膜厚と磁束密度 $B_{2 \mathrm{k}}$ の関係における, 磁 性皮膜を被覆した粉未の粒径の影響を示す. 膜厚が厚くなる と磁束密度 $B_{2 \mathrm{k}}$ が低下して, 同じ膜厚においては粉末粒径が大 きいほど磁束密度 $B_{2 \mathrm{k}}$ が増加した。つまり, 圧粉成形体に占め る鉄粉の割合が多いほど磁束密度 $B_{2 \mathrm{k}}$ は増加することが確認

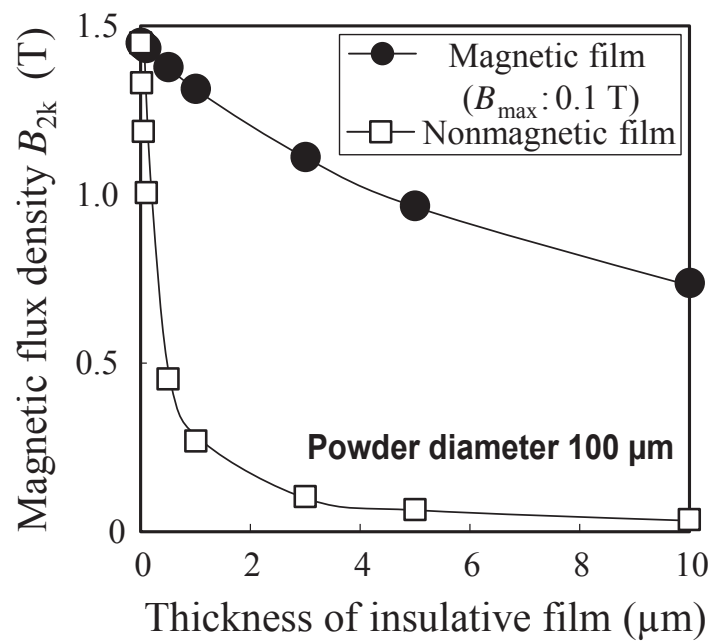

Fig. 3 Effect of magnetism of insulating film.
できた.

Fig. 5 には磁性皮膜の飽和磁化と膜厚による磁束密度 $B_{2 \mathrm{k}}$ の 変化を示す. 粉末粒径は $100 \mu \mathrm{m}$ とした. 高い飽和磁化の磁性 体を絶縁皮膜へ導大する方が, 磁束密度 $B_{2 \mathrm{k}}$ が向上しており, 高磁束密度化に有利であることが計算で認められた。

3.2 スピネル型フェライト被覆粉の特性

前述した計算結果を検証するため, スピネル型フェライト 粉を被覆した鉄粉で成形したリング試験片の特性評価を行っ た。磁性絶縁皮膜の膜厚と各特性 (密度, 透磁率, 磁束密度 $B_{2 \mathrm{k}}$ および比抵抗)の関係を調べるため, まず, スピネル型フエ ライト粉の混合量よって生じる絶縁皮膜の膜厚を測定した. 皮膜厚さの測定にはオージェ電子分光分析 (AES) を用いた. 被覆粉の表面から皮膜の厚さ方向に酸素の分布を測定し, 表 面の酸素強度の $50 \%$ にる厚さをフェライト皮膜の膜厚とし た. 測定值は, 粉末 1 個当り 2 箇所を, 粉末 2 個で分析して 求めた值の平均值である.Fig.6にスピネル型フェライトの被 覆粉のオージェ電子分光分析の結果と断面 SEM 像を示す.

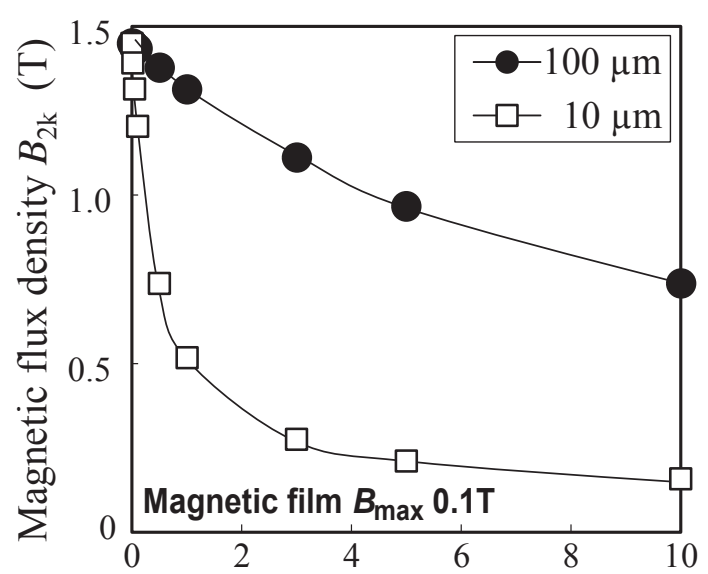

Thickness of insulative film $(\mu \mathrm{m})$

Fig. 4 Effect of particle diameter.

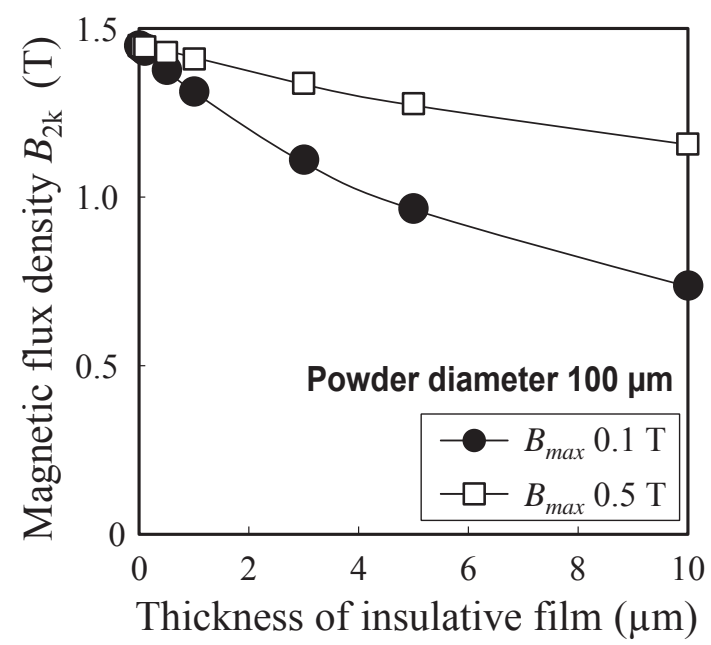

Fig. 5 Effect of $B_{\max }$ of magnetic insulating film. 


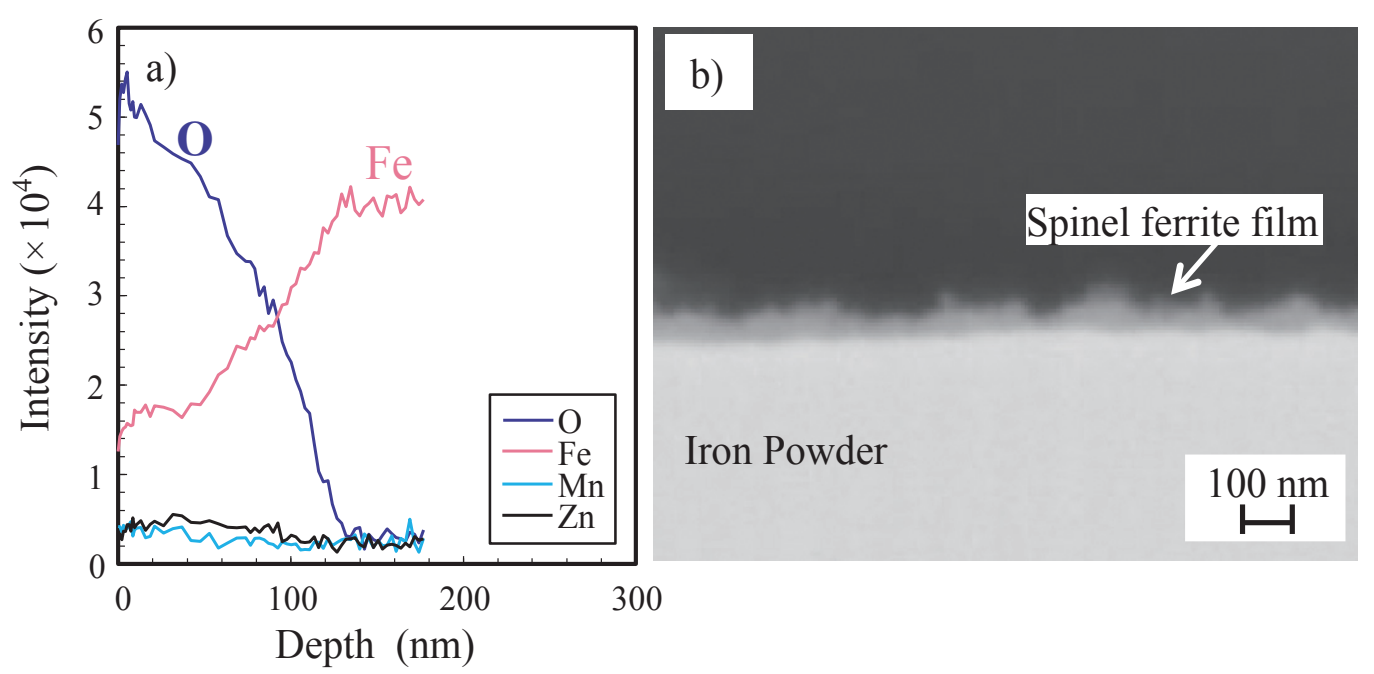

Fig. 6 Measurement of spinel ferrite film thickness. (a) Analysis result of AES depth spectrum, and (b) SEM image of cross section of powder.

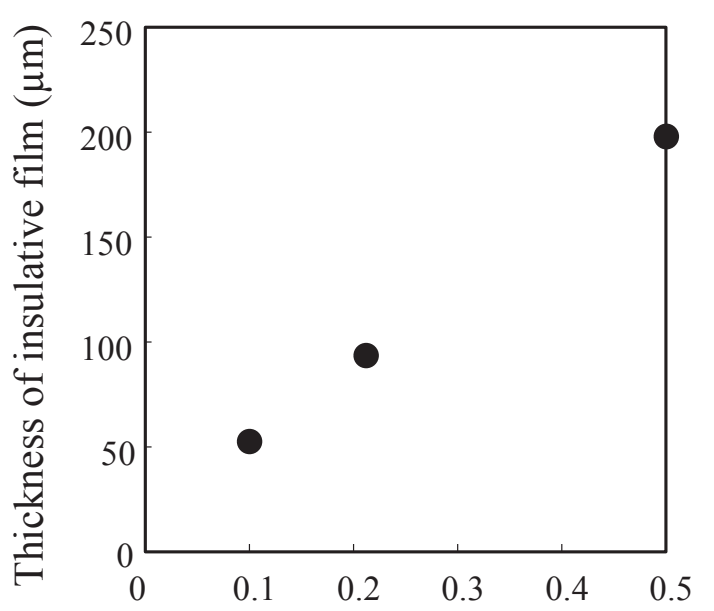

Mixed quantity of ferrite powders (mass $\%$ )

Fig. 7 The relation between addition quantity of spinel ferrite powders and film thickness (*Film thickness is analyzed by AES depth spectrum).

Fig. 6 (a) で示す表面の酸素強度 52000 の $50 \%$ になる酸素強度 26000 の膜厚が約 $100 \mathrm{~nm}$ となり，Fig. 6 (b) の被覆粉の断面を 直接観察して測定した膜厚 $100 \mathrm{~nm}$ とほぼ一致した. Fig. 7 に スピネル型フェライトの混合量とオージェ電子分光分析で測 定した絶縁皮膜の膜厚の関係を示す.0.1 mass\%のスピネル型 フェライトの混合量で約 $50 \mathrm{~nm}, 0.5 \mathrm{mass} \%$ を混合すると約 $200 \mathrm{~nm}$ の膜厚を示した.

Fig.8 8 磁性絶縁皮膜の膜厚に扔ける密度, 比抵抗, 磁束密 度 $B_{2 \mathrm{k}}$ および磁束密度 $B_{20 \mathrm{k}}$ の変化を示す。絶縁皮膜が厚くなる と, 比抵抗が増加し絶縁性は向上するが, 密度と磁束密度 $B_{2 \mathrm{k}}, B_{20 \mathrm{k}}$ が低下した．被覆粉の膜厚 $50 \mathrm{~nm}$ の場合，比抵抗 $=70$ $\mu \Omega \cdot \mathrm{m}$, 密度 $=7.79 \mathrm{Mg} / \mathrm{m}^{3}$, 磁束密度 $B_{2 \mathrm{k}}=1.4 \mathrm{~T}$, 磁束密度 $B_{20 \mathrm{k}}=$ $1.96 \mathrm{~T}$, また膜厚 $100 \mathrm{~nm}$ の場合, 比抵抗 $=100 \mu \Omega \cdot \mathrm{m}$, 密度 $=$
$7.78 \mathrm{Mg} / \mathrm{m}^{3}$, 磁束密度 $B_{2 \mathrm{k}}=1.3 \mathrm{~T}$, 磁束密度 $B_{20 \mathrm{k}}=1.95 \mathrm{~T}$ の圧 粉体が得られた.この結果から, スピネル型フェライトの絶 縁皮膜への適用で高比抵抗と高磁束密度の特性が得られるこ とが確認された。

Fig.9にスピネル型フェライト被覆粉の表面状態(Fig.9(a)) と圧粉体断面(Fig.9 (b)) のSEM像を示す. 被覆表面が殆ど均 一に被覆されており, 断面像からも緻密で均一皮膜が観察さ れた.スピネルフェライト粉を単純混合によって被覆しても， 均一に被覆が可能で, 高磁束密度と高比抵抗を両立する圧粉 体が得られることが分かった。

3.3 磁性絶縁皮膜による高磁束密度化の効果

磁性皮膜と非磁性皮膜の圧粉磁心の磁束密度 $B_{2 \mathrm{k}}$ の実験値 を計算値と比較するため, 原料磁性粉末のみ，およびリン酸 塩皮膜を被覆した被覆粉を同じ1568 MPaの成形圧力でリング 試験片を作製した. Fig. 10 に磁性抢よび非磁性絶縁皮膜の膜 厚に対する磁束密度 $B_{2 \mathrm{k}}$ の実験值と計算值をプロットして示 す. 非磁性皮膜であるリン酸塩皮膜の膜厚は被覆粉の断面 SEM 像から直接測定し, リン酸塩皮膜の膜厚が約 $100 \mathrm{~nm}$ と なることがわかった。 そのリン酸塩皮膜を被覆した被覆粉の 断面 SEM 像を Fig. 11 に示す. 磁性皮膜と非磁性皮膜の圧粉 磁心の磁束密度 $B_{2 k}$ は, 膜厚が厚くなると值が低下するが, 非 磁性絶縁皮膜に比べて磁性皮膜の磁束密度 $B_{2 \mathrm{k}}$ が高い值を示 した. また磁性絶縁皮膜における膜厚 $100 \mathrm{~nm}$ までの磁束密度 $B_{2 \mathrm{k}}$ の変化傾向が計算值と実験值でほぼ一致していることがわ かる. 非磁性絶縁皮膜でも膜厚 $100 \mathrm{~nm}$ における実験值と計算 值が良く一致した。

しかし, 被覆粉の膜厚 $200 \mathrm{~nm}$ 以上, つまり圧粉体の膜厚で はその 2 倍に近い $400 \sim 500 \mathrm{~nm}$ の膜厚では計算値と実験值に 乘離が大きくなった. 計算値には入力した皮膜の膜厚以外の 空陌は生じないと仮定していることに対して, 実際の成形時 には被覆粉の間に空隙が生じて圧粉体の密度が低下する. 膜 厚 $200 \mathrm{~nm}$ 以上で計算值と実験值に乘離が大きくなることは, 

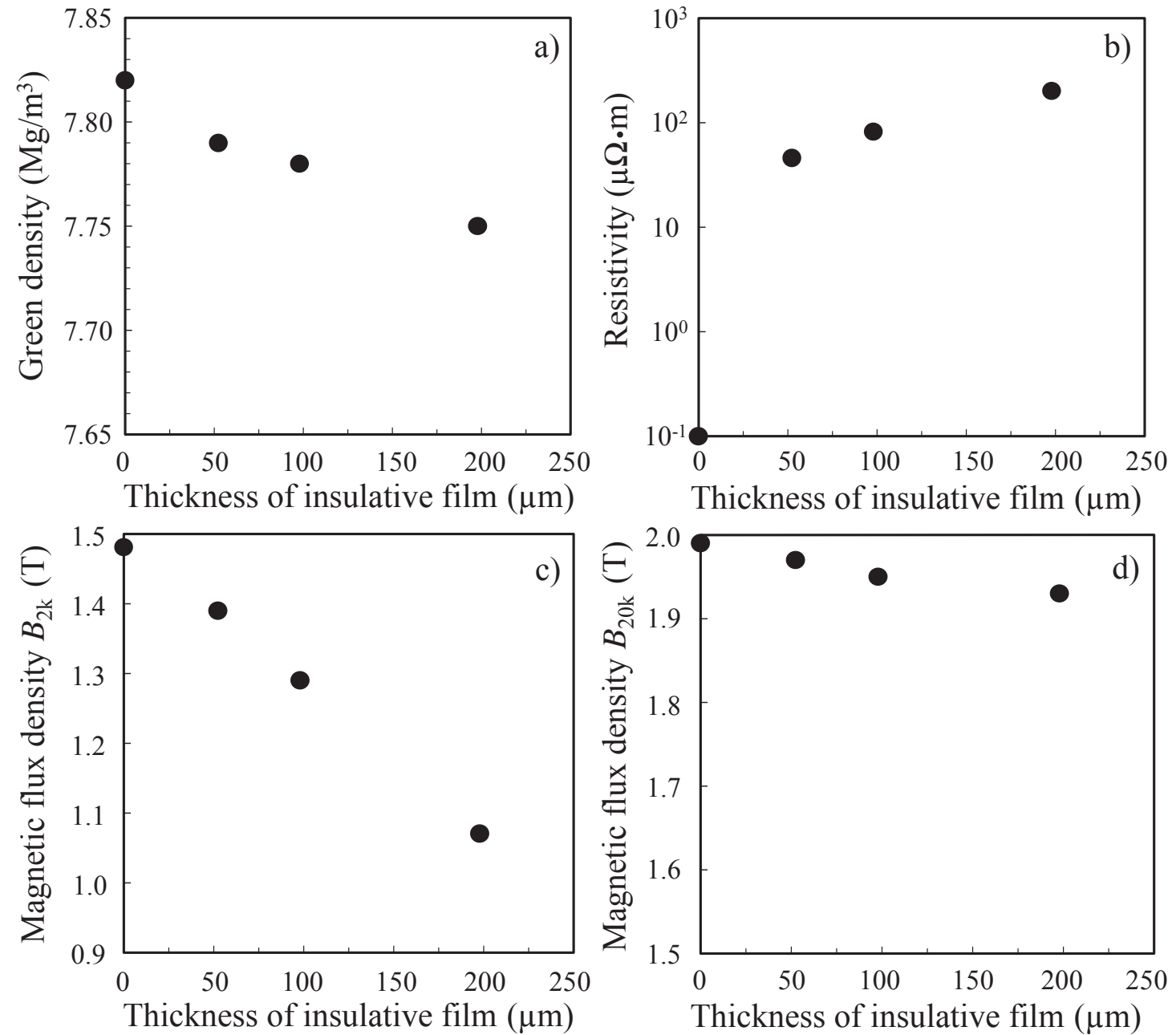

Thickness of insulative film $(\mu \mathrm{m})$

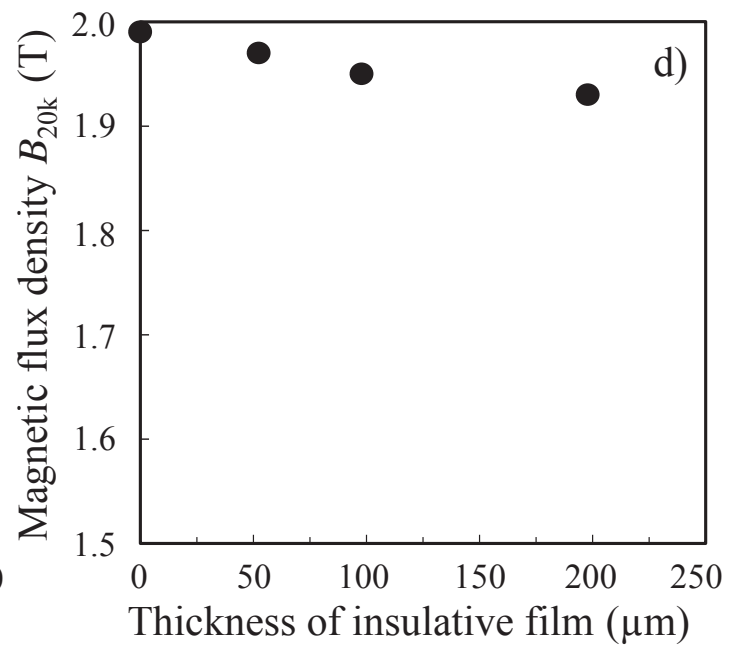

Fig. 8 Effect of insulting film thickness on the properties.
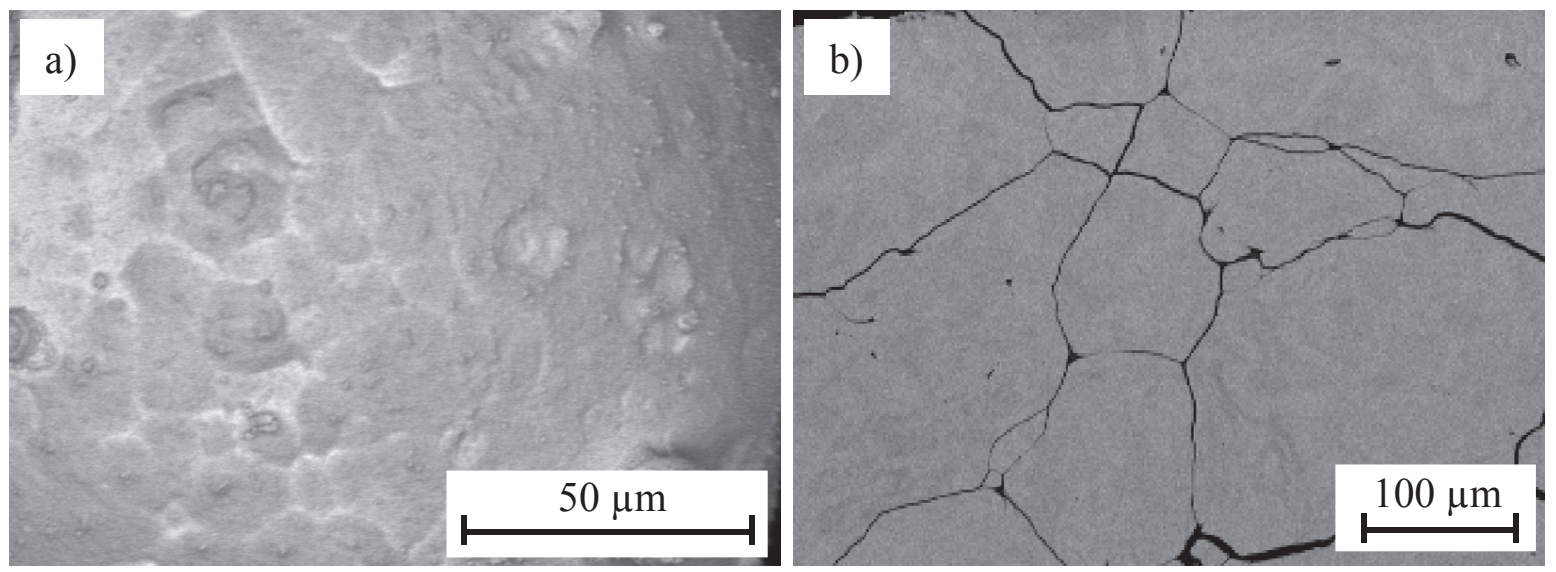

Fig. 9 SEM images of (a) surface of powder coated by spinel ferrite, and (b) cross section of magnetic core.

その空隙発生に起因する密度低下が原因の一つであると推察 される.

Fig. 12に磁性絶縁皮膜と非磁性絶縁皮膜を有する圧粉磁心 の圧粉体密度による磁束密度 $B_{2 k}$ の変化を示す. 圧粉体密度の 増加により磁束密度 $B_{2 k}$ が向上しており, 同じ密度では磁性皮
膜の磁束密度 $B_{2 k}$ が非磁性皮膜より高い值を示した. Table 1 に同じ比抵抗 $100 \mu \Omega \cdot \mathrm{m}$ を有する磁性皮膜と非磁性皮膜の圧 粉磁心における圧粉体密度, 比抵抗, 磁束密度 $B_{2 \mathrm{k}}$ および $B_{20 \mathrm{k}}$ の評価結果を, またその両絶縁皮膜の圧粉磁心の $B H$ 曲線を Fig. 13 に示した. 


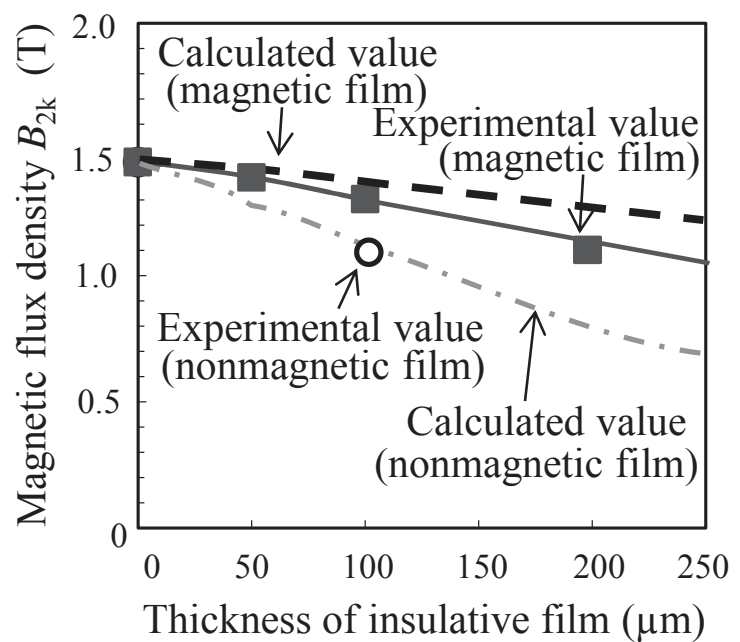

Fig. 10 Comparison between experimental and calculated value (magnetic flux density $B_{2 \mathrm{k}}$ ).

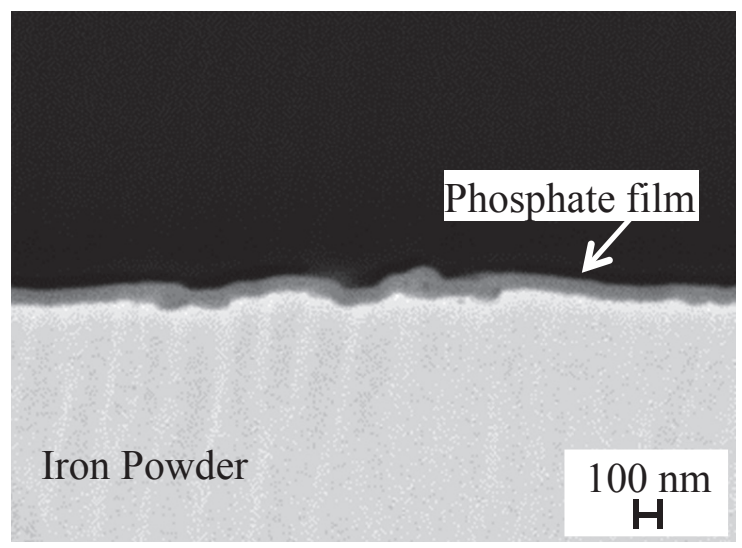

Fig. 11 SEM image of cross section of powder plated by nonmagnetic film.

これらの結果から, スピネル型フェライトの被覆による絶 縁皮膜の磁性化により, 絶縁性を確保しながら圧粉磁心の高 磁束密度化が可能であることが認められた。

\section{4 ま と め}

磁性絶縁皮膜による圧粉磁心の高磁束密度化の可能性を検 討するため, スピネル型フェライト粉を混合被覆した鉄粉を 成形した圧粉体の特性を評価し, 以下の結果を明らかにした.

(1) スピネル型フェライトを絶縁皮膜に導入した圧粉体の磁 束密度を評価した結果, 計算值と実験值が概ね一致した。 計算結果により, 磁性絶縁皮膜による高磁束密度化の効 果は, 膜厚が厚くなるほど, 粉末粒径が大きいほど, 顕著 であることが分かった。

(2) 同じ比抵抗を有する非磁性絶縁皮膜に比べ，磁性絶縁皮 膜の圧粉磁心の方が高い磁束密度を示した．絶縁皮膜の 磁性化することにより，圧粉磁心の高磁束密度化ができ た.

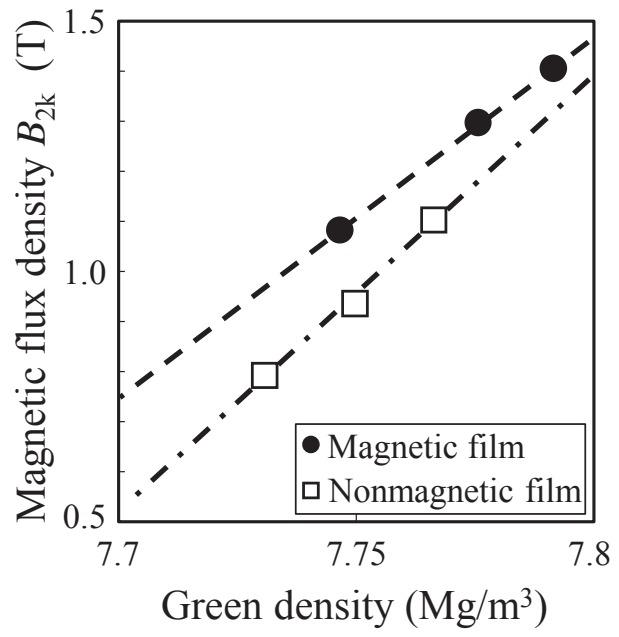

Fig. 12 Comparison of magnetic flux density $B_{2 \mathrm{k}}$ between magnetic film core and nonmagnetic film core.

Table 1 The properties of powder magnetic cores with magnetic insulating film and nonmagnetic insulating film using by figure 13 .

\begin{tabular}{|c|c|c|c|c|}
\hline & $\begin{array}{c}\text { Green density } \\
\left(\mathrm{Mg} / \mathrm{m}^{3}\right)\end{array}$ & $\begin{array}{c}\text { Resitivity } \\
(\mu \Omega \cdot \mathrm{m})\end{array}$ & $\begin{array}{c}B_{2 \mathrm{k}} \\
(\mathrm{T})\end{array}$ & $\begin{array}{c}B_{20 \mathrm{k}} \\
(\mathrm{T})\end{array}$ \\
\hline Magnetic film & 7.78 & 100 & 1.29 & 1.95 \\
\hline Nonmagnetic film & 7.77 & 100 & 1.10 & 1.86 \\
\hline
\end{tabular}

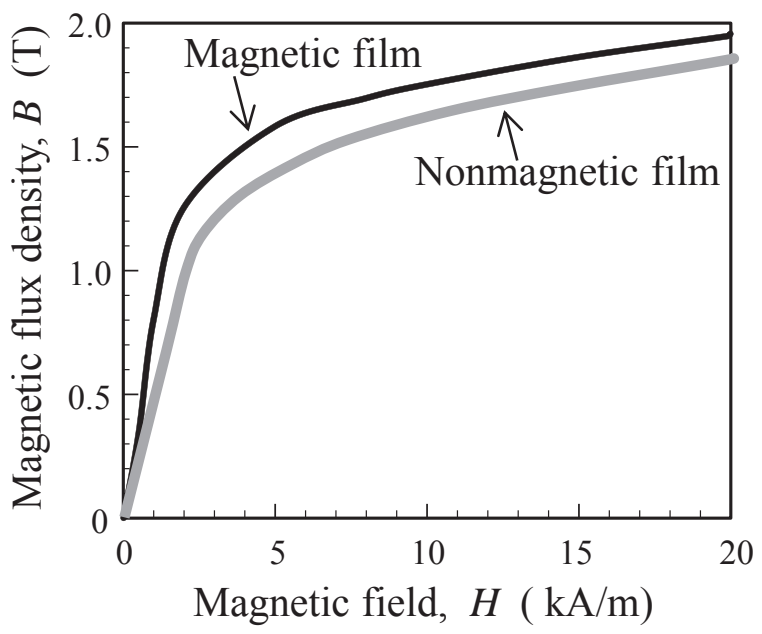

Fig. 13 Initial magnetization curves of magnetic film and nonmagnetic film core.

(3) スピネル型フェライト粉を混合被覆した鉄粉を $1568 \mathrm{MPa}$ の成形圧力で成形した圧粉体で, 比抵抗 $=70 \mu \Omega \cdot \mathrm{m}$, 密 度 $=7.79 \mathrm{Mg} / \mathrm{m}^{3}$, 磁束密度 $B_{2 \mathrm{k}}=1.4 \mathrm{~T}$ の特性が得られ, ス ピネル型フェライトによる圧粉体の絶縁化の可能性を確 認した。 


\section{文献}

1) Y. Ozaki, M. Fujinaga: "Magnetic Properties of High Permeability Iron Powder KIP MG270H for Line Filter Cores", Kawasaki Steel Giho, 31(1999)130-134.

2) H. Mitani, A. Hanaki, H. Yaguchi, Y. Seki: "Magnetic Properties of Dust cores made with Inorganic Insulation coated Iron powder", Kobe Steel Engineering Reports, 48(1998)2528.

3) T. Saito, S. Yahagi: "Electromagnetic Properties of Compressed cores with $\mathrm{Fe}-\mathrm{Si}$-Al system Atomized Powders", Denkiseiko, 69(1998)181-187.

4) Y.Shimada, K. Matsunuma, T. Maeda, T. Nishioka, A. Ikegaya: "Development of High-Performance P/M Soft Magnetic Material", J. Jpn. Soc. Powder Powder Metallurgy, 55-2(2008) 149-151.

5) K. Kanagawa, K. Mori, R. Nakayama: "Charaterization of High-speed Motor using Dust cores", Abstracts of Autumn Meeting JSPM, (2005)138.

6) Y. Enomoto, M. Ito, R. Masaki, K. Asaka: "Characteristic Examination of New Synchronous Motor that Composes Craw Teeth of Soft Magnetic Composite", IEEJ Trans. Industry Applications, 126-11(2006)1585-1590.

7) D. Kim, M. Ohnishi, N. Matsushita, M. Abe: "Magnetic Cores Usable in Gigahertz Range: Permalloy/Ni-Zn Ferrite Microcomposite made by Low-Temperature Wet Process", IEEE Mag. Trans., 39-5(2003)3181-3183.

8) N. Matsushita, D. Kim, M. Abe: "High-Flux Desity and LowCore Losses Attained for Ferrite / Permalloy Composite Core", IEEE Mag. Trans., 42-10(2006)2824-2826.

9) M. Abe, Y. Tamaura: "Ferrite-Plating in Aqueous Solution: A New Method for Preparing Magnetic Thin Film", Jpn. J. Appl.
Phys., L511(1983)22.

10) M. Abe: "Ferrite-Film Formation from an Aqueous Solution, and Applications", J. of Mag. Soc. Jpn., 22-9(1998) 1225-1232.

11) K. Fujimura, M. Kato, K. Hirota: "Fabrication of $\mathrm{Mg}-\mathrm{Fe}-\mathrm{O}$ Ferrite/Magnetic Metal Bulk Composites by High-Pressure Sintering", J. Jpn. Soc. Powder Powder Metallurgy, 55-9(2008) 629-636.

12) M. Obata, M. Kato, K. Hirota: "Fabrication of Mg Ferrite/ permalloy Magnetic Nano-composites", J. Jpn. Soc. Powder Powder Metallurgy, 57-10(2010)672.

13) S. Tajima, T. Hattori, S. Hotta, M. Kondoh, H. Okajima, K. Higashiyama, H. Kishimoto: "Properties of high density magnetic composite (HDMC) by warm compaction using die wall lubrication", J. Jpn. Soc. Powder Powder Metallurgy, 50 (2003) 577-583.

14) Y. Kawase, T. Yamaguchi, T. Takemoto, K. Hiramoto, H. Nakai: "Eddy current analysis of soft magnetic composites using 3-D finite element method", The Papers of Technical Meeting IEEJ, RM-07-98(2007)69-72.

15) S. Tajima, T. Hattori, M. Kondoh, H. Kishimoto, M. Sugiyama, T. Kikko: "Properties of high density magnetic composite (HDMC) fabricated from iron particles coated with new type phosphrate insulator", J. Jpn. Soc. Powder Powder Metallurgy, 52(2005) 164-170.

16) M. Kondoh, H. Okajima: "High density powder compaction using die wall lubrication", Advances in Powder Metallurgy \& Particulate Materials, 3(2002)47-54.

17) S. Tajima, T. Hattori, M. Kondoh, M. Sugiyama, K. Higashiyama, H. Kishimoto, T. Kikko: "Properties of high density magnetic composite (HDMC) by warm compaction using die wall lubrication", Mater. Trans., 45(2004)1891-1894. 